\title{
Three New Species and New Records of Dennstaedtia Bernh. from Mesoamerica
}

\author{
Alexander Francisco Rojas-Alvarado ${ }^{1}{ }^{*}$, Federico Villalobos-Brenes ${ }^{2}$ \\ ${ }^{1}$ Universidad Nacional de Costa Rica, Heredia, Costa Rica \\ ${ }^{2}$ Laboratory of Systematic, Genetic and Evolution (LabSGE), Escuela de Ciencias Biológicas, Universidad Nacional, \\ Heredia, Costa Rica \\ Email: ^alfrojasa@yahoo.com
}

How to cite this paper: Rojas-Alvarado, A.F. and Villalobos-Brenes, F. (2018) Three New Species and New Records of Dennstaedtia Bernh. from Mesoamerica. Open Access Library Journal, 5: e5020. https://doi.org/10.4236/oalib.1105020

Received: November 2, 2018

Accepted: December 10, 2018

Published: December 13, 2018

Copyright $@ 2018$ by authors and Open Access Library Inc.

This work is licensed under the Creative Commons Attribution International License (CC BY 4.0).

http://creativecommons.org/licenses/by/4.0/

\begin{abstract}
Navarrete \& Øllgaard [1] indicated the presence of a "C" group within Dennstaedtia Bernh. that contains D. obtusifolia (Willd.) T. Moore, which is the type material of the genus Patania C. Presl and indicated that it could require taxonomic recognition. They also discussed the situation generated by other authors including $D$. cornuta (Kaulf.) Mett. and D. obtusifolia as synonyms for $D$. dissecta (Sw.) T. Moore and then separated them as valid species; however, they insist on mentioning variables within the mentioned species and indicated that other species could be included. As a result of this group's review from Costa Rica, it was found that there are three easily distinguishable new species: D. axillaris A. Rojas, D. rectangularis A. Rojas and D. riparia A. Rojas. Also, D. cornuta is registered from Mexico and Guatemala, and D. sprucei T. Moore is registered from Costa Rica.
\end{abstract}

\section{Subject Areas}

Biology, Botany, Taxonomy

\section{Keywords}

Dennstaedtia Bernh., D. dissecta Complex, Ferns, New Taxa, Patania C. Presl

\section{Introduction}

The genus Dennstaedtia Bernh., is characterized by having commonly terrestrial habitat (sometimes hemiepiphytic or epiphytic) with creeping rhizome and it without scales (hairy or setose), patent frond to $7 \mathrm{~m}$ long and $1.5 \mathrm{~m}$ broad, herbaceous laminar tissue, sorus over a vein and indusium bivalve to cyathiform $[2]$. 
Dennstaedtia is a genus with approximately 45 species, principally in tropical to temperate regions of world [3]. Tryon [4] made the revision of the genus from America and Tryon y Tryon [5] defined tentatively 11 species from the continent. Through new regional studies [1] [6], near 22 species are registered from America and specifically from Costa Rica 13 species are mentioned. At the beginning of the century, Navarrete \& Øllgaard [1] described three new species from Ecuador; after that, Rojas y Tejero [2] described a new species from Mexico. In this work, three new species more are described from Mesoamerica.

\section{Materials and Methods}

The new species were compared with related species in different taxonomic treatments from Mesoamerica and South America (Gómez \& Arbeláez [7], Mickel \& Smith [8], Moran [6], Murillo et al. [9], Navarrete \& Øllgaard [1], Tryon \& Stolze [10] and Yañez et al. ([11] 2014). In addition the collections of: Museo Nacional de Costa Rica (CR), Herbario Nacional de México (MEXU), Universidad de Costa Rica herbarium (USJ) and Instituto de Ecología (XAL) were consulted. The examined specimens are deposited in the following herbaria $\mathrm{CR}, \mathrm{MEXU}$, USJ and XAL (acronyms following Thiers, [12]). To ensure the correct application names, original type material or digital type images were examined as available (Jstor Global Plants (http://plants.jstor.org/)), and the new names were corroborated with International Plant Name Index (http://www.ipni.org/ipni/plantnamesearchpage.do).

\section{Results}

In this paper three new species are described and two species are registered from different countries in Mesoamerica.

\subsection{New Species}

\subsubsection{Dennstaedtia axilaris}

\section{A. Rojas, sp. nov. (Figure 1)}

1) Type: COSTA RICA. Heredia: Sarapiquí, Puerto Viejo, Estación Biológica La Selva, nearest grid post $1800: 1450,10^{\circ} 26^{\prime} \mathrm{N}, 84^{\circ} 01^{\prime} \mathrm{W}, 50 \mathrm{~m}, 6$ Sep 2001, $M$. Jones \& P. Olivas 249 (Holotype: CR).

2) Diagnoses: Dennstaedtia axilaris A. Rojas differs from D. dissecta (Sw.) T. Moore by its thinner rhizome; shorter fronds; axes with acicular and brown hairs throughout; more equilateral pinnules; and one sori in the axil of segments.

3) Description: Rhizome $0.8-1.3 \mathrm{~cm}$ in diameter, short-creeping, sparsely setose to glabrescent, the setae $2-5 \times$ less than $0.5 \mathrm{~mm}$ long, brown; fronds 0.9 $1.5 \mathrm{~m}$ long, arching; stipe (30-) $45-75 \mathrm{~cm}$ long, strawish to brown, opaque, glabrous or with very sparse hairs, less than $0.5 \mathrm{~mm}$ long, hyaline; blade $60-75$ $\times 45-55 \mathrm{~cm}$, ovate to lanceolate, 2-pinnate-pinnatifid, green and opaque adaxially, more clear abaxially, without axillar buds, hairy only in the axes; rachis strawish to brown, liso (sin espinas); basal and medial pinnae $23-28 \times 7-10$ 
cm, linear-lanceolate, subsessil, acuminate at apex; pinnules $1.7-3.2 \times 0.7-1.4$ $\mathrm{cm}$, lanceolate to shortly oblong, lobulate to pinnatifid, sessil and decurrent at base, rounded to acute and dentate at apex, the basal one of basal pinnae reduced, the medial ones equilateral to slightly inequilateral; axes without herbaceous and perpendicular wings adaxially; costae and main veins of pinnules, densely hairy abaxially, the hairs 0.2 - $0.5 \mathrm{~mm}$ long, acicular, thin, brown throughout; lobes to $0.8 \times 0.6 \mathrm{~mm}$, slightly falcate, entire; secondary veins sparsely hairy, the hairs as costae, brown; segments $3-7 \mathrm{~mm}$ broad, obtuse to truncate at apex; apex of sterile veins claviform; sori 1 (rarely 2 in the basal acroscopic lobe) in the axil between lobules; indusia $0.5-0.7 \times 0.9-1.2 \mathrm{~mm}$, bulliform to cyathiform, entire and brown marginally.

4) Etimology. The name of it species make reference to the presence of sorionly in the axil of segments.

5) Distribution: Known only from Caribbean side of Nicaragua and North slope of Cordillera Central in Costa Rica at 50 - 900 m.

6) Additional revised material: COSTA RICA. Heredia: Sarapiquí, Puerto Viejo, La Selva Biological Station, nearest grid post 400:200, 23 Oct 2001, M. Jones \& P. Olivas 317 (CR); ibídem., nearest grid post 2400:850, 2 May 2002, M. Jones \& $P$. Olivas 440 (CR).

NICARAGUA. Managua: Las Nubes, Casa Colorada, ca. 900 m, Nov 1976, L. Gómez \& Villa 6452 (CR). Zelaya: 22 miles of Rama, over road to Juigalpa, at edge of tributary Río Mico, 400 m, Nov 1976, L. Gómez \& Cittar 6445 (CR).

7) Notes. Dennstaedtia axilaris differs from $D$. dissecta by its costae and main veins with hairs 0.2 - $0.5 \mathrm{~mm}$ long, acicular, thin and brown throughout (vs. 0.1 $0.3 \mathrm{~mm}$ long, linear-lanceolate to linear, expanded at base and brown only in the onion between cells), and sori in the axil of broad and obtuse lobes (vs. sori in the axil narrow, acute and falcate lobes). Figure 1 shows pinna detail with axillar sori of broad and obtuse lobes.

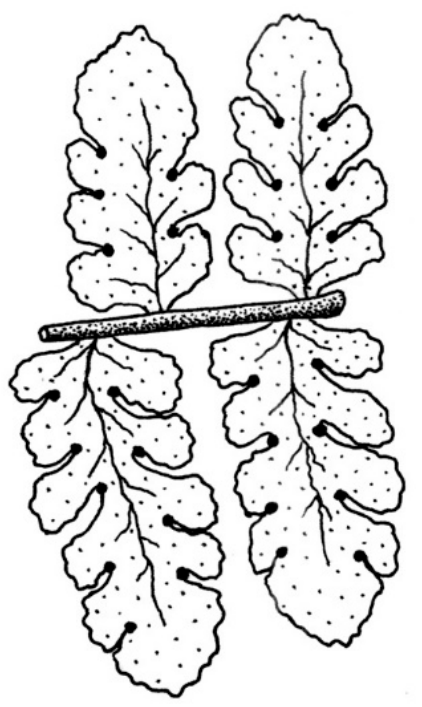

Figure 1. Dennstaedtia axilaris. pinna detail (M. Jones \& P. Olivas 249 (CR)). 


\subsubsection{Dennstaedtia rectangularis}

\section{A. Rojas, sp. nov. (Figure 2)}

1) Type: COSTA RICA. San José: Vásquez de Coronado, La Palma area, NE of San Jeronimo, above La Hondura valley, $10^{\circ} 02^{\prime} \mathrm{N}, 84^{\circ} 00^{\prime} \mathrm{W}, 1500 \mathrm{~m}, 27$ May - 1 Jun 1968, W. Burger \& R. Stolze 5273 (Holotype: CR; Isotype: F?).

2) Diagnoses: Dennstaedtia rectangularis A. Rojas differs from $D$. dissecta (Sw.) T. Moore by its rectangular segments and they with truncate apex, and one the sori1-3 in superior side over the margin.

3) Description: Rhizome not seen, probably short-creeping, no branched; fronds $1.3-2.2 \mathrm{~m}$ long, stipe $0.6-1 \mathrm{~m}$ long; blade $70-120 \times 60-90 \mathrm{~cm}$, ovate-lanceolate, 3-pinnate to 3-pinnate-lobulate, slightly reduced at base, papiraceous to chartaceous; pinnae $30-45.5 \times 15-20 \mathrm{~cm}$, alternate to suboposite, with basal pinnules (at less of the basal and medial pinnae) reduced, without axilar gems; pinnules $8-10 \times 2-2.8 \mathrm{~cm}$, lanceolate, equilateral, without acroscopic lobe, truncate at base or slightly expanded, caudate at apex; pinnulules or segments $1-1.4 \times 0.4-0.7 \mathrm{~mm}$, rectangular, inequilateral, basiscopically excavate and attenuate with the axes, acroscopically expanded, obtuse to truncate and entire to lobulateat apex; apex of sterile veins claviform; sori 1 - 3 in the superior side and 0 to rarely 1 in the inferior side; indusia $0.5-0.7 \times 0.7-1.0 \mathrm{~mm}$, bulliform to cyathiform, entire and brown marginally.

4) Etimology. The name of it species make reference to the rectangular segments.

5) Distribution: Known only from North slopes of Cordillera Central at 1400 $-1500 \mathrm{~m}$.

6) Additional revised material: COSTA RICA. San José: Vásquez de Coronado, La Hondura, 1400 m, 20 Jul 1927, M. Valerio 173 “32802” (CR).

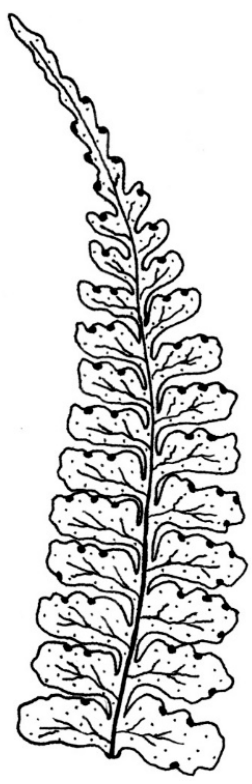

Figure 2. Dennstaedtia rectangularis: pinnule detail (W. Burger \& R. Stolze 5273 (CR)). 
7) Notes. Dennstaedtia rectangularis differs from $D$. dissecta by its rectangular (vs. triangular) segments with obtuse to truncate and entire to lobulate apex (vs. segments with acute and dentate apex) and sori 1-3 in superior side over the margin (vs. sori 1 in the axil between lobes. Figure 2 shows pinnule detail with rectangular segments and obtuse to truncate and entire to lobulate apex.

\subsubsection{Dennstaedtia riparia}

A. Rojas, sp. nov. (Figure 3)

1) Type: COSTA RICA. Cartago: Turrialba, Valle del Reventazón, Jicotea, La Pradera Farm, $9^{\circ} 47^{\prime} 15^{\prime \prime N}, 83^{\circ} 32^{\prime} 35^{\prime \prime} \mathrm{W}, 1000$ m, 22 Jun 1995, G. Rivera \& A. Rojas 2479 (holotype: CR).

2) Diagnoses: Dennstaedtia riparia A. Rojas differs from D. dissecta (Sw.) T. Moore by its 2-pinnate-pinnatifid and glabrous blade, segments with obtuse to truncate and entire to lobulate apex and bigger indusia.

3) Description: Rhizome $1-1.5 \mathrm{~cm}$ in diameter, short-creeping, rigid, scaly, glabrescent at maturity, the scales $1.5-3 \times$ less $0.5 \mathrm{~mm}$, linear, broadly at base; fronds 1.75 - $2.35 \mathrm{~m}$ long, arching to scandent; stipe $80-115 \mathrm{~cm}$ long, opaque, glabrous or with very sparse hairs, less than $0.5 \mathrm{~mm}$ long, hyaline; blade $95-120$ $\times 70-100 \mathrm{~cm}$, ovate to lanceolate, 2-pinnate-pinnatifid, dark green and lustrous adaxially, more clear abaxially, without axillar buds, glabrous in both surfaces; basal and medial pinnae $35-50 \times 12.5-17.5 \mathrm{~cm}$, linear-lanceolate, subsessil; basal pinnules reduced, medial pinnules entire to pinnatisect, sessil and decurrent

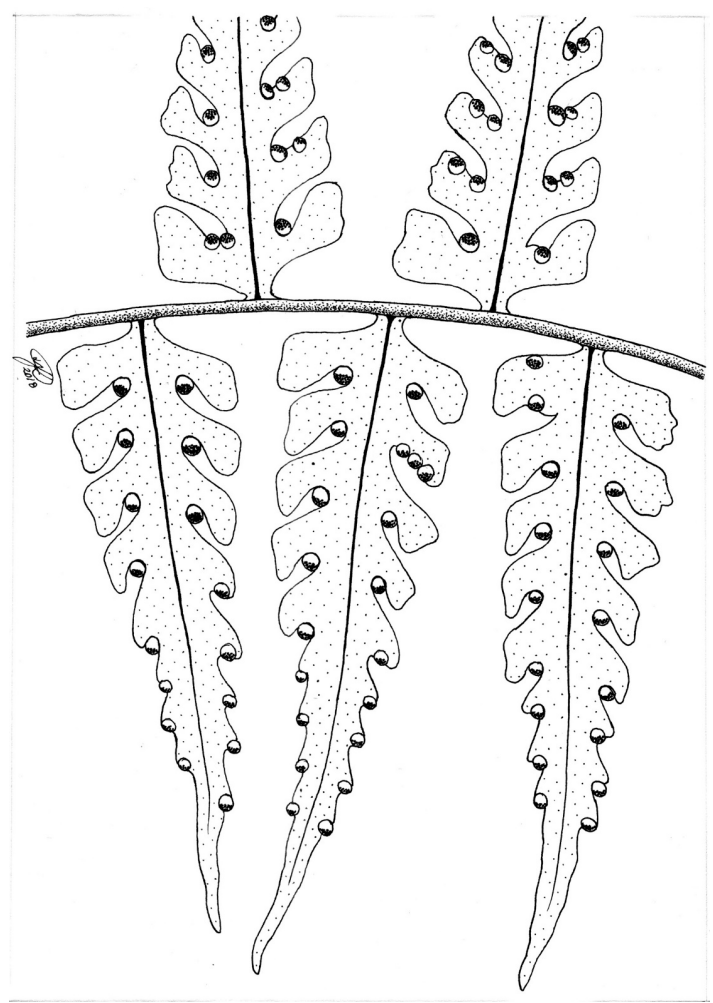

Figure 3. Dennstaedtia riparia: pinna detail (G. Rivera y A. Rojas 2479 (CR). 
at base, long acuminate to caudate at apex; axes without herbaceous and perpendicular wings adaxially, glabrous to sparsely hairy abaxially, the hairs $0.1-0.2$ mm long, hyaline; segments (3-) $5-8 \mathrm{~mm}$ broad, obtuse to truncate at apex; apex of sterile veins not claviform; sori $1(-3)$ in the axil between lobules; indusia $0.7-1 \times 1.2-1.8 \mathrm{~mm}$, bulliform to cyathiform, strawish and entire marginally.

4) Etimology. The name of it species make reference to the rectangular segments.

5) Distribution: Known only from North slopes of Cordillera de Tilarán and Caribbean slopes of Cordillera de Talamanca at $700-1000 \mathrm{~m}$.

6) Additional revised material: COSTA RICA. Alajuela: Cantón de San Ramón, Reserva Biológica Alberto Manuel Brenes, La Cascada, ca. $1 \mathrm{~km}$ W de la estación, $10^{\circ} 53^{\prime} \mathrm{N}, 85^{\circ} 24^{\prime} \mathrm{W}, 700 \mathrm{~m}, A$. Rojas et al. 5438 (USJ, MO).

7) Notes. Dennstaedtia riparia differs from $D$. dissecta by its 2-pinnate-pinnatifid (vs. 3-pinnate-pinnatifid) blade, glabrous (vs. hairy over the veins) blade, segments with obtuse to truncate and entire to lobulate apex (vs. segments with acute and dentate apex) and bigger indusia (0.7 - $1 \times 1.2-1.8 \mathrm{~mm}$ vs. $0.5-0.8 \times$ $0.7-1.0 \mathrm{~mm}$ ). Figure 3 shows segments with obtuse to truncate and entire to lobulate apex, also axillar sori.

\subsection{New Records}

\subsubsection{Dennstaedtia cornuta}

(Kaulf.) Mett., Ann. Sci. Nat., Bot., sér. 5, 2: 260. 1864. Dicksonia cornuta Kaulf., Enum. Filic. 227. 1824. Type: Brazil, “Sprengel communicavit”, Sello s.n. (B).

1) Known distribution: Mexico, Guatemala, Costa Rica, Panama and South America.

2) Material of new distribution: MEXICO. Chiapas: Municipio of Rayón, Selva Negra, $10 \mathrm{~km} \mathrm{~N}$ above Rayón, Mezcalapa along road to Jitotol, 1700 m, 25 Jan 1973, D. Breedlove \& A. Smith 32328 (MEXU). Guerrero: Atoyac de Álvarez, $\mathrm{km} 10$ of the trail from Puerto del Gallo to Atoyac, 2060 m, 11 Jan 1983, F. Lorea 2347 (MEXU). Oaxaca: Ixtlán, Sierra de Juárez, 8 km S of Vista Hermosa, 71 km $\mathrm{N}$ of Ixtlán de Juárez, on rute 175, 5400 ft. [1646 m], 23 Sep 1972, J. Mickel \& L. Pardue 6733 (MEXU); ibídem, 5600 ft. [1707 m], 23 Sep 1972, J. Mickel \& L. Pardue 6748 (MEXU); road Textepec-Oaxaca, 9 Dec 1984, M. Palacios 2339 (XAL). Veracruz: Alto Lucero, Cerro de La Cima, between La Sombra and Tierra Blanca, $19^{\circ} 46^{\prime} \mathrm{N}, 96^{\circ} 41^{\prime} \mathrm{W}, 1700$ m, 10 Apr, 1981, G. Castillo \& F. Vázquez 1539 (XAL); Cuautlanillo (Orizaba), 1500 m, 1 Mar 1938, E. Copeland 71 (MEXU).

GUATEMALA. Chiquimula: Esquipulas, Trifinio, $14^{\circ} 30^{\prime} 28^{\prime \prime} \mathrm{N}, 89^{\circ} 23^{\prime} 8.5^{\prime \prime} \mathrm{W}$, 1797 m, 7 Aug, 2005, M. Véliz \& J. Vargas 15898 (MEXU).

3) Notes. Dennstaedtia cornuta is similar to D. obtusifolia (Willd.) T. Moore in falcate fertile lobes, but $D$. cornuta is a species of lower elevations with smaller fronds and narrower sterile segments.

\subsubsection{Dennstaedtia sprucei}

T. Moore, Index Filic. 308. 1861. Type: Ecuador, Spruce 5350 (holotype: K!; Iso- 
types: B!, BM!, C, COL! frag., GH!, LE!, NY!, P!, SI!, US! frag.; photo: US, QCA).

1) Known distribution: Costa Rica, Colombia and Ecuador.

2) Material of new distribution: COSTA RICA. Puntarenas: Osa, Fila Costeña, headers of Piedras Blancas river; Cerro Anguciana, foot steeps O, $08^{\circ} 48^{\prime} 36^{\prime \prime} \mathrm{N}, 083^{\circ} 10^{\prime} 12^{\prime \prime} \mathrm{W}, 1400-1600$ m, 10 Dec 1993, B. Hammel 19265 (CR, $\mathrm{MO})$.

3) Notes. This is the only record of the species from Mesoamerica.

\section{Conflicts of Interest}

The authors declare no conflicts of interest regarding the publication of this paper.

\section{References}

[1] Rojas, A.F. (2000) The Fern Genus Dennstaedtia (Dennstaedtiaceae) in Ecuador; New Characters, New Species and New Combination. Nordic Journal of Botany, 20, 319-346. https://doi.org/10.1111/j.1756-1051.2000.tb00747.x

[2] Rojas, A.F. and Tejero, D. (2002) Una especie nueva de Dennstaedtia (Filicales: Dennstaedtiaceae) para México. Revista de Biología Tropical, 50, 1007-1012.

[3] Kramer, K.U. (1990) Dennstaedtiaceae. In: Kubitzki, K., Ed., Families and Genera of Vascular Plants, Part 1. Pteridophytes and Gymnosperms, Springer-Verlag, 81-94.

[4] Tryon, R.M. (1960) A Review of the Genus Dennstaedtia in America. Contributions from the Gray Herbarium of Harvard University, 187, 23-52.

[5] Tryon, R.M. and Tryon, A.F. (1982) Ferns and Allied Plants, with Special Reference to Tropical America. Springer-Verlag, New York, i-xii. 1-857.

https://doi.org/10.1007/978-1-4613-8162-4

[6] Moran, R.C. (1995) Dennstaedtia. In: Moran, R.C. and Riba, R., Eds., Flora Mesoamericana. Volumen 1. Psilotaceae a Salviniaceae, Universidad Nacional Autónoma de México. D. F., México, 150-163. http://www.mobot.org/mobot/tropicos/meso/homep_sp.htm

[7] Gómez, L.D. and Arbeláez, A.L. (2009) Flora de Nicaragua. Tomo IV: helechos. Missouri Botanical Garden, St. Louis, 348 p.

[8] Mickel, J.T. and Smith, A.R. (2004) The Pteridophytes of Mexico. Memoirs of New York Botanical Garden, 88, 1-1029.

[9] Murillo, M.T., Murillo, J., León, A. and Triana, L.A. (2008) Los Pteridófitos de Colombia. Arfo. Bogotá, DC, 533 p.

[10] Tryon, R.M. and Stolze, R.G. (1989) Pteridophyta of Peru: Part 1. 1. Ophioglossaceae 12. Cyatheaceae. Fieldiana Botany New Series, 20, 1-145.

[11] Yañez, A, Arana, M.D., Márquez, G.J. and Oggero, A. (2014) The Genus Dennstaedtia Bernh. (Dennstaedtiaceae) in Argentina. Phytotaxa, 174, 69-81.

https://doi.org/10.11646/phytotaxa.174.2.1

[12] Thiers, B. (2016) [continuously updated] Index Herbariorum: A Global Directory of Public Herbaria and Associated Staff. New York Botanical Garden's Virtual Herbarium. http://sweetgum.nybg.org/science/ih/ 